\title{
CORPORATE SOCIAL RESPONSIBILITY W SEKTORZE MŚP
}

Z a r y s t r e ś c i: Idea Corporate Social Responsibility swoimi korzeniami sięga filozoficznej koncepcji odpowiedzialności, zgodnie z którą następstwem obdarowania człowieka wolnością jest nałożenie na niego odpowiedzialności. Prowadzenie działalności gospodarczej w dobie niestabilnego otoczenia wymaga od właścicieli sformułowania i przestrzegania takiej strategii działania, która poza osiąganiem wymiernych korzyści finansowych, przyczyni się do rozwoju najbliższego środowiska firmy. Implementacja założeń społecznej odpowiedzialności biznesu w mniejszych podmiotach jest pośrednio ograniczona ze względu na błędną interpretację istoty koncepcji, a nawet brak znajomości samego pojęcia wśród przedsiębiorców. Niniejszy artykuł ma charakter teoretyczno-przeglądowy. W publikacji opisano przykłady dobrych i złych praktyk CSR-owych stosowanych przez polskie i międzynarodowe przedsiębiorstwa. Analizie poddane zostało także spektrum wykorzystywanych przez te podmioty narzędzi odpowiedzialnego prowadzenia działalności gospodarczej.

S ł o w a k 1 u c z o w e: CSR; społeczna odpowiedzialność biznesu; sektor MŚP.

\section{WSTĘP}

Od wielu dekad na całym świecie trwa dyskurs dotyczący charakteru oraz priorytetów prowadzenia działalności gospodarczej. Wśród przedsiębiorców dominuje pogląd, że celem funkcjonowania firmy powinno być osią-

* Adres do korespondencji: Agnieszka Drews, Uniwersytet Mikołaja Kopernika w Toruniu, Wydział Nauk Ekonomicznych i Zarządzania, Katedra Zarządzania Przedsiębiorstwem, ul. Gagarina 13a, 87-100 Toruń, e-mail: agnieszkadrews90@gmail.com 
ganie zysku, rozumianego wyłącznie w kategoriach finansowych. Jednakże wzrost konkurencji i świadomości społecznej implikuje konieczność uwzględniania również kwestii pozafinansowych, a co za tym idzie prowadzenia dialogu ze wszystkimi interesariuszami. Narzędziem ułatwiającym osiągnięcie równowagi między biznesem a otoczeniem jest koncepcja społecznej odpowiedzialności biznesu (CSR $\left.{ }^{1}\right)$, stosowana na szeroką skalę już w wieku XIX w czasie amerykańskiej „ery przedsiębiorców”. Każdy podmiot funkcjonuje w określonym środowisku społeczno-lokalnym, na które może wywierać wpływ - zarówno pozytywny, jak i negatywny. Kształtowanie wiarygodności oraz dobrej reputacji przedsiębiorstwa staje się, obok kwestii stricte finansowych, kluczowym elementem umożliwiającym zdobycie przewagi konkurencyjnej we współczesnej gospodarce. Przeważającą formą prowadzenia działalności gospodarczej w krajach europejskich są małe i średnie przedsiębiorstwa (MSP). Owe podmioty stają się coraz bardziej odpowiedzialne, co potwierdza szereg badań przeprowadzonych przez gremia ekspertów. Celem artykułu jest deskrypcja oraz identyfikacja narzędzi CSR wykorzystywanych przez polskie i europejskie podmioty należące do sektora małych i średnich przedsiębiorstw. W poniższych rozważaniach autorka przedstawiła informacje pochodzące z raportu Polskiej Agencji Rozwoju Przedsiębiorczości nt. stanu wdrażania standardów społecznej odpowiedzialności biznesu w Polsce.

\section{TEORETYCZNE UJĘCIE SPOŁECZNEJ ODPOWIEDZIALNOŚCI BIZNESU}

W literaturze przedmiotu istnieje wiele interpretacji terminu społecznej odpowiedzialności biznesu. Pojęcie CSR jest bezpośrednio powiązane z etyką biznesu, a jej początki europejskie datuje się na $1891 \mathrm{r}$., kiedy to powstała encyklika Leona XII Rerum Novarum (o kwestii robotniczej). Trzy dekady później, za sprawą książki E.W. Lord The Fundamentals of Business Ethics, pojęcie społecznej odpowiedzialności zaistniało na gruncie amerykańskim. W kolejnych latach nastąpiła adaptacja wartości etycznych w naukach ekonomicznych, która przyczyniła się do stopniowej zmiany mentalności przedsiębiorców - zwłaszcza w kwestii sposobów osiągania zysku [Polańska, 1997, s. 317]. Rozkwit etyki biznesu stanowi fundament

1 ang. Corporate Social Responsibility 
do podjęcia dyskusji na temat kształtu i wyzwań współczesnej społecznej odpowiedzialności biznesu.

Rozpowszechnienie idei CSR skutkuje powstawaniem kolejnych definicji (zob. tab. 1) wskazujących kierunek przewodni koncepcji społecznej odpowiedzialności biznesu. Mnogość wytycznych uniemożliwia określenie zamkniętego instrumentarium działań odzwierciedlających przedsiębiorstwa odpowiedzialne. Amerykański ekonomista Friedman, jako jeden z nielicznych, utożsamia odpowiedzialność biznesu z powiększaniem zysków. Podkreśla również konieczność funkcjonowania na rynku według zasad fair play. Organizacje międzynarodowe uwypuklają w definicji CSR etyczne zachowania przedsiębiorstw oraz ich odpowiedzialność za konkretne grupy interesariuszy. $Z$ kolei przedstawiciele polskiego środowiska naukowego akcentują zachowanie równowagi między potrzebami firmy i najbliższego otoczenia, a także prowadzenie działalności według zasad zrównoważonego rozwoju. Komisja Europejska pod koniec 2011 r. zmodyfikowała własną definicję społecznej odpowiedzialności, umieszczoną dekadę wcześniej w Zielonej Księdze. Nowy zapis określa CSR jako „odpowiedzialność przedsiębiorstw za ich wpływ na społeczeństwo”. Komisja określa także warunki wstępne do przyjęcia zasad CSR - poszanowanie obowiązującego prawa oraz ograniczenie negatywnego wpływu przedsiębiorstwa na środowisko lokalne połączone z maksymalizacją wartości dla interesariuszy [Komisja Europejska, 2011, s. 7].

Tabela 1. Przegląd terminologii społecznej odpowiedzialności biznesu.

\begin{tabular}{|l|l|}
\hline \multicolumn{1}{|c|}{ Autor } & \multicolumn{1}{c|}{ Definicja } \\
\hline M. Friedman & $\begin{array}{l}\text { „zwiększanie zysków i podejmowanie otwartej konkurencji } \\
\text { według zasad etycznych, zgodnych z ustalonymi regułami } \\
\text { gry” }\end{array}$ \\
\hline $\begin{array}{l}\text { Światowa Rada Biznesu ds. } \\
\text { Zrównoważonego Rozwoju }\end{array}$ & $\begin{array}{l}\text { „ciągłe zobowiązanie biznesu do etycznego zachowania } \\
\text { oraz przyczyniania się do rozwoju ekonomicznego, przy } \\
\text { równoczesnej poprawie jakości życia siły roboczej i jej } \\
\text { rodzin, jak również lokalnej społeczności i społeczeństwa } \\
\text { jako ogółu” }\end{array}$ \\
\hline J. Adamczyk & $\begin{array}{l}\text { „zobowiązanie do transparentnego i etycznego prowadze- } \\
\text { nia działalności według zasad zrównoważonego rozwoju } \\
\text { oraz dazżenie do dobrobytu społecznego, uwzględniając } \\
\text { oczekiwania interesariuszy zgodnie z prawem i normami } \\
\text { zachowań” }\end{array}$ \\
\hline
\end{tabular}


Cd. tab. 1

\begin{tabular}{|l|l|}
\hline \multicolumn{1}{|c|}{ Autor } & \multicolumn{1}{c|}{ Definicja } \\
\hline $\begin{array}{l}\text { Międzynarodowa Organiza- } \\
\text { cja Normalizacyjna (ISO) }\end{array}$ & $\begin{array}{l}\text { „odponiedzialność organizacji za wpływ jej decyzji i dzia- } \\
\text { na społeczeństwo i środowisko poprzez przejrzyste } \\
\text { i etyczne zachowania, które przyczyniają się do rozwoju, } \\
\text { zdrowia i dobrobytu społecznego" }\end{array}$ \\
\hline B. Zinczuk & $\begin{array}{l}\text { "wrażliwość na sprawy otoczenia zewnętrznego, zdolność } \\
\text { do utrzymania równowagi pomiędzy interesami klientów, } \\
\text { pracowników i akcjonariuszy, a także świadczenia pew- } \\
\text { nych usług na rzecz społeczności lokalnej” }\end{array}$ \\
\hline
\end{tabular}

Źródło: Friedman, 1997, s. 114; World Business Council for Sustainable Development,2002, s. 6; Adamczyk, 2009, s. 10; ISO, 2010, s. 3; Zinczuk, 2011, s. 68.

Po zapoznaniu się z wybranymi definicjami CSR występującymi w literaturze przedmiotu, niezbędne do zobrazowania omawianych kwestii jest przedstawienie podstawowych płaszczyzn społecznej odpowiedzialności biznesu. Godna uwagi jest koncepcja prof. Carrolla, który stworzył piramidę odpowiedzialności przedsiębiorstwa - analogiczną do piramidy potrzeb A. Maslowa.

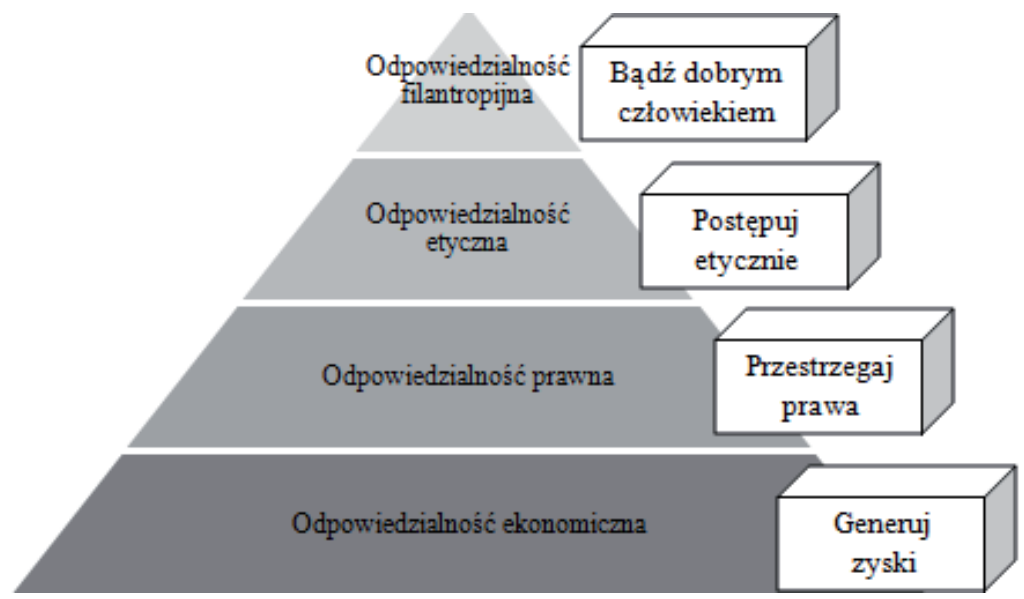

Schemat 1. Piramida odpowiedzialności A. B. Carrolla

Źródło: opracowanie własne na podstawie Carroll, 1991, s. 39-48. 
Powyższa koncepcja zakłada, że tak jak człowiek, przedsiębiorstwo w pierwszej kolejności musi zaspokoić podstawowe potrzeby - w tym przypadku podejmować właściwe decyzje strategiczne, tworzyć miejsca pracy i generować zysk. Zapewnienie odpowiedzialności ekonomicznej stanowi fundament do osiągania kolejnych szczebli hierarchii odpowiedzialności biznesu [Klepacka, 2008, s. 10]. Do potrzeb wyższego rzędu przedsiębiorstwa (zob. schemat 1) zalicza się kolejno: odpowiedzialność prawną, odpowiedzialność etyczną oraz odpowiedzialność filantropijną. Często przedsiębiorcy popełniają błąd, utożsamiając CSR wyłącznie z działalnością dobroczynną. Zakładając, że „ważne jak firma zarabia pieniądze, a nie na co je wydaje" błędne jest wskazywanie obszaru, który ma z założenia wymiar altruistyczny [Bachorski-Rudnicki, Kroik, 2012, s. 3]. W tym miejscu należałoby podkreślić, że prawdziwe motywy prowadzenia działalności gospodarczej nie zmieniły się na przestrzeni lat - wciąż cele ekonomiczne są na pierwszym miejscu. Sceptycy koncepcji CSR zarzucają przedsiębiorcom, że cele społeczne zaczęły być przez nich realizowane dopiero wówczas, gdy dostrzeżono ich pozytywny wpływ na wynik finansowy firmy [Kazojć, 2012, s. 38].

Przedsiębiorstwo, które zastanawia się nad inicjacją działań społecznie odpowiedzialnych, staje przed sporym dylematem. Występuje bowiem wiele problemów społecznych do rozwiązania - istotne jest wybranie właściwego obszaru i odbiorców podejmowanych inicjatyw. Międzynarodowa Organizacja Normalizacyjna (ISO) wyróżnia 7 podstawowych płaszczyzn CSR, w obrębie których powinny zostać zintensyfikowane działania firm odpowiedzialnych. Należą do nich: ład organizacyjny, prawa człowieka, relacje z pracownikami, środowisko naturalne, uczciwe praktyki rynkowe, relacje z konsumentami oraz zaangażowanie społeczne i rozwój społeczności lokalnej [ISO, 2010, s. 4]. Przykłady podejmowanych przez przedsiębiorstwa działań w wymienionych obszarach zostały szerzej opisane w drugim podrozdziale niniejszej publikacji.

Ostatnim omawianym wątkiem w tej części pracy jest lista narzędzi stosowanych w zarządzaniu społeczną odpowiedzialnością. Do najczęściej stosowanych instrumentów należą [FOB, www.odpowiedzialnybiznes. $\mathrm{pl}, 2015 \mathrm{a}]$ :

- kampanie społeczne - tj. działania zorientowane na zmianę zachowań konkretnej grupy osób (np. Prędkość zabija - włącz myślenie),

- marketing zaangażowany społecznie - przedsięwzięcia akcentujące jednocześnie cele marketingowe oraz potrzeby społeczne (np. akcje Centrum Krwiodawstwa Twoja krew, moje życie), 
- programy etyczne, wolontariat pracowniczy - mające na celu zjednoczenie osób zatrudnionych wokół wspólnych wartości bądź podjęcie działań na rzecz potrzebujących,

- raportowanie spoleczne - tzn. proces opracowania i opublikowania dokumentacji, która w przejrzysty sposób odzwierciedla sposób zarządzania i właściwego prowadzenia działalności podmiotu,

- ograniczenie emisji odpadów i zanieczyszczeń zarówno w zakładach pracy, jak i poprzez optymalizację m.in. procesów logistycznych.

\section{PRZYKŁADY DOBRYCH I ZŁYCH PRAKTYK CSR}

Współczesne przedsiębiorstwa, w związku z próbami nawiązywania interakcji z najbliższym otoczeniem, nie mogą wyłącznie „nie szkodzić”, lecz powinny odgrywać rolę „dobrego sąsiada”. Pierwsze kodeksy dobrych praktyk, traktujące nt. działań amerykańskich przedsiębiorców, wprowadzono w RPA pod nazwą Zasad Sullivana [Bernatt, 2009, s. 24]. Zakazywały one dyskryminowania pracowników pochodzenia afrykańskiego, m.in. w sferze warunków pracy, wysokości płacy czy obejmowania stanowisk kierowniczych [NationMaster, www.nationmaster.com, 2015].

Niestety, koncepcja społecznej odpowiedzialności biznesu daje możliwość szerokiej interpretacji jej założeń. Taki stan rzeczy często jest wykorzystywany przez przedsiębiorców, którzy są świadomi, iż konsument jest w stanie zapłacić więcej za produkt wytworzony z poszanowaniem zasad etycznych [Krasek, Skwiercz, 2007, s. 71]. Na podstawie raportu FOB „Odpowiedzialny biznes w Polsce 2014" stworzono tabelę zawierającą przykłady dobrych i zarazem nietuzinkowych praktyk realizowanych przez firmy różnej wielkości. 
Tabela 2. Nietypowe praktyki odpowiedzialnych przedsiębiorstw w Polsce w 2014 r.

\begin{tabular}{|c|c|}
\hline $\begin{array}{c}\text { Obszar społecznej } \\
\text { odpowiedzialności } \\
\text { biznesu }\end{array}$ & Nazwa firmy i realizowane przedsięwzięcie \\
\hline ŁAD ORGANIZACYJNY & $\begin{array}{l}\text { Schenker sp. z o.o. - program szkoleniowy w formie gry } \\
\text { planszowej „Fair Play” } \\
\text { W grze biorą udział grupy 5-osobowe, podczas której utrwa- } \\
\text { lana jest znajomość obowiązujących w pracy wytycznych. } \\
\text { Jedna rozgrywka trwa ok. } 3-4 \text { h. Pracownicy odpowiadają } \\
\text { na trzy rodzaje pytań: Co wiesz?, Co byś zrobił gdyby?, Jaka } \\
\text { jest Twoja opinia? Do końca stycznia } 2015 \text { r. przeszkolono } \\
\text { wszystkich pracowników firmy. }\end{array}$ \\
\hline PRAWA CZŁOWIEKA & $\begin{array}{l}\text { Otto Polska sp. z o.o. - „Prawdziwy talent nie ma barier” } \\
\text { Projekt ma na celu aktywizację zawodową osób niepełno- } \\
\text { sprawnych. W } 2014 \text { r. zatrudniono w firmie } 16 \text { osób z nie- } \\
\text { pełnosprawnościami, co stanowi } 15 \% \text { ogółu pracowników. }\end{array}$ \\
\hline $\begin{array}{l}\text { RELACJE } \\
\text { Z PRACOWNIKAMI }\end{array}$ & $\begin{array}{l}\text { Grupa Raben - Konkurs „Tańczący z paletami” } \\
\text { Turniej organizowany jest dla operatorów wózków widło- } \\
\text { wych i ma na celu propagowanie bezpiecznych zachowań } \\
\text { w magazynie. W oddziałach lokalnych przeprowadzona była } \\
\text { I tura, na którą składała się część teoretyczna i praktyczna. } \\
\text { II tura konkursu - dla zwycięzców starć lokalnych odbyła się } \\
\text { w centrali firmy. Trzem najlepszym operatorom wózków wi- } \\
\text { dłowych wręczono kryształowe palety i nagrody pieniężne. }\end{array}$ \\
\hline $\begin{array}{l}\text { ŚRODOWISKO } \\
\text { NATURALNE }\end{array}$ & $\begin{array}{l}\text { JARS - kontrola okolicznych akwenów wodnych } \\
\text { Przedsiębiorstwo monitorowało specjalistycznym sprzętem } \\
\text { czystość wody w Zalewie Zegrzyńskim i pobliskich wód. } \\
\text { Przeprowadzono łącznie } 10 \text { analiz kontrolnych, których wy- } \\
\text { niki opublikowano w lokalnej prasie. }\end{array}$ \\
\hline $\begin{array}{l}\text { UCZCIWE PRAKTYKI } \\
\text { RYNKOWE }\end{array}$ & $\begin{array}{l}\text { PKN Orlen SA - blog informacyjno-edukacyjny } \\
\text { Główny ekonomista firmy prowadzi blog edukacyjny, któ- } \\
\text { ry stanowi istotną formę komunikacji z interesariuszami. } \\
\text { Umożliwia również bieżące prezentowanie stanowisk firmy } \\
\text { oraz komentowanie aktualnych wydarzeń z zakresu ekono- } \\
\text { mii, polityki klimatycznej i zrównoważonego rozwoju. }\end{array}$ \\
\hline
\end{tabular}


Cd. tab. 2

\begin{tabular}{|c|c|}
\hline $\begin{array}{c}\text { Obszar społecznej } \\
\text { odpowiedzialności } \\
\text { biznesu }\end{array}$ & Nazwa firmy i realizowane przedsięwzięcie \\
\hline $\begin{array}{l}\text { RELACJE Z KONSUMEN- } \\
\text { TAMI }\end{array}$ & $\begin{array}{l}\text { ING Bank Śląski - „Videotłumacz języka migowego” } \\
\text { Przedsięwzięcie ma przyczynić się do ograniczenia barier } \\
\text { osób z dysfunkcją słuchu, które porozumiewają się języ- } \\
\text { kiem migowym. W I fazie projektu przeszkolono wybranych } \\
\text { pracowników z zasad postępowania z osobami niedosły- } \\
\text { szącymi. W II fazie projektu, poprzez nawiązanie współpra- } \\
\text { cy z portalem Migam.pl, w dwóch oddziałach detalicznych } \\
\text { w Katowicach i Warszawie wdrożono rozwiązanie videotłu- } \\
\text { macza. W momencie pojawienia się klienta posługującego } \\
\text { się językiem migowym w placówce pracownik nawiązuje po- } \\
\text { łączenie internetowe z certyfikowanym tłumaczem. }\end{array}$ \\
\hline $\begin{array}{l}\text { ZAANGAŻOWANIE SPO- } \\
\text { ŁECZNE I ROZWÓJ SPO- } \\
\text { ŁECZNOŚCI LOKALNEJ }\end{array}$ & $\begin{array}{l}\text { IKEA Reatail - projekt „Strefa Rodzica” } \\
\text { Firma podjęła się aranżacji pomieszczeń szpitalnych, które } \\
\text { mają być przeznaczone dla rodziców opiekujących się dzieć- } \\
\text { mi znajdującymi się na oddziale szpitala w Łodzi. }\end{array}$ \\
\hline
\end{tabular}

Źródło: opracowanie własne na podstawie FOB, 2015b, s. 21-115.

Opracowania dotyczące społecznej odpowiedzialności biznesu w zdecydowanej większości zawierają wyłącznie przykłady dobrych praktyk CSR-owych. Niewiele mówi się o nadużyciach kadr kierowniczych, manipulacjach opinią publiczną i ukrytych motywach bycia odpowiedzialnym. W tym miejscu należy zadać pytanie: Czy można nazywać firmę etyczną, jeżeli cyklicznie wspiera lokalne ośrodki wychowawcze i jednocześnie nie wypłaca wynagrodzenia pracownikom w terminie? Odpowiedź jest jednoznaczna - nie. Innym przykładem jest postępowanie jednej z firm ubezpieczeniowych, która zapewnia 10-dniowy turnus rekonwalescencyjny dla dzieci, które w wypadku straciły rodziców. Pozornie idea wydaje się szlachetna, jednak podłoże tych działań ma charakter wyłącznie materialny. Firma od pewnego czasu borykała się z rosnącą liczbą odwołań klientów od decyzji dot. wypłaty i wysokości odszkodowań. Większość roszczeń, które trafiły na drogę sądową, rozpatrywane były na korzyść wnioskodawców. Wobec tego ubezpieczyciel musiał wypłacić dodatkowe świadczenia. W ciągu kilku miesięcy od wprowadzenia programu pomocowego zauwa- 
żono znaczący spadek liczby wniosków apelacyjnych od wydanej przez firmę ubezpieczeniową decyzji.

Niespójne działania firm i oświadczenia sprzeczne ze stanem faktycznym zakłócają odbiorcom przejrzysty obraz społecznej odpowiedzialności biznesu. Problemem staje się odróżnienie aktywności społecznej od działalności komercyjnej przybierającej etyczne oblicze [Stafiej, Prochenko, 2004, s. 37].

\section{POZIOM ZAAWANSOWANIA STANDARDÓW CSR W POLSKICH MSP - WYNIKI BADAŃ PARP}

Komisja Europejska w 2014 r. opublikowała raport dotyczący polityki społecznej odpowiedzialności biznesu realizowanej w poszczególnych krajach Unii Europejskiej. Zdaniem autorów raportu świadomość CSR w polskich firmach z sektora MSP znajduje się we wczesnej fazie rozwoju [Williamson i in., 2014, s. 26]. Pośrednio może to wynikać z faktu, że mniejsze firmy wpierają lokalne otoczenie, nie przypisując swoim działaniom rangi społecznej odpowiedzialności [Ministerstwo Gospodarki, 2010, s. 5].

W 2011 r., pod egidą Polskiej Agencji Rozwoju Przedsiębiorczości, na próbie 850 polskich przedsiębiorstw (z $89 \%$ udziałem firm z sektora MSP) przeprowadzone zostały badania odnoszące się do znajomości i realizacji koncepcji CSR. Niestety, zaledwie 31\% przedstawicieli polskich firm twierdzi, że zna definicję społecznej odpowiedzialności biznesu - są to w większości firmy duże, istniejące na rynku ponad 15 lat i aktywnie współpracujące z kontrahentami zagranicznymi. Ankietowani utożsamiają pojęcie CSR głównie z kształtowaniem dobrych relacji z pracownikami, kontrahentami i klientami (22\%), troska o środowisko naturalne (21\%) oraz uczciwościa w stosunku do interesariuszy (19\%) [Skrzek-Lubasińska i in., 2011, s. 52]. Można zatem wywnioskować, że 4 na 7 obszarów społecznej odpowiedzialności wyróżnionych przez ISO są właściwie identyfikowane przez polskich przedsiębiorców z koncepcją CSR. Spośród przedstawicieli przedsiębiorstw deklarujących znajomość pojęcia społecznej odpowiedzialności biznesu, ok. ${ }^{2} / 3$ wdraża działania z nią związane - najmniejszy odsetek wskazań w sektorze MSP wystąpił wśród przedstawicieli mikrofirm (56\%), a najwyższy w małych przedsiębiorstwach (80\%) [Skrzek-Lubasińska i in., 2011, s. 55]. 
Respondenci zostali również zapytani, które z wymienionych obszarów CSR są istotne dla ich rozwoju oraz czy wskazane zasady są przez nich urzeczywistniane. Wyniki zaprezentowano na poniższym wykresie.

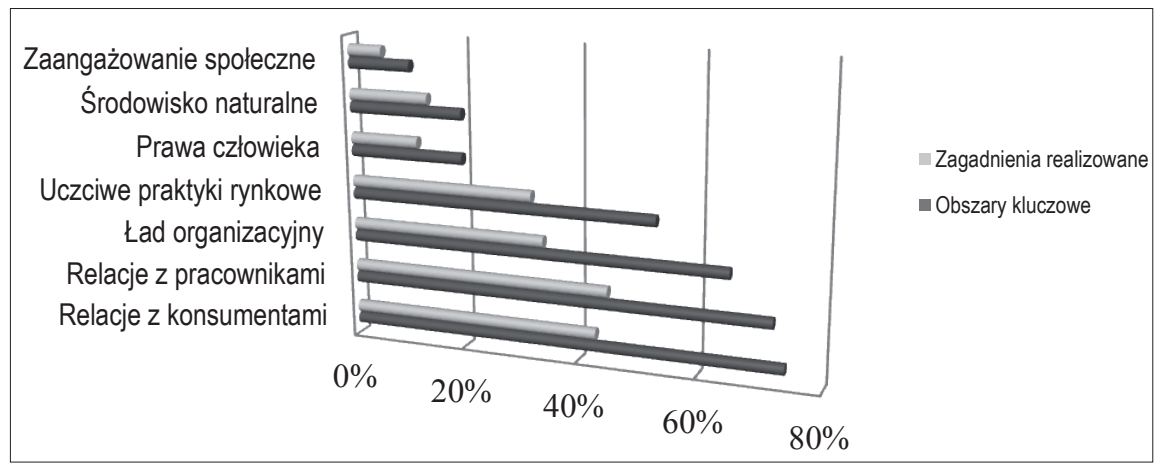

Wykres 1 . Kluczowe obszary CSR - założenia a realizacja $(\mathrm{N}=870)$

Źródło: opracowanie własne na podstawie Lubasińska i in., 2011, s. 60.

Do kluczowych obszarów wpływających na rozwój danej firmy w zdecydowanej większości zaliczono relacje z konsumentami (74\%) oraz z pracownikami (72\%). Równie wysoko ankietowani ocenili organizację pracy w firmie oraz stosowanie uczciwych praktyk rynkowych - odpowiednio $65 \%$ i 53\% wskazań. Powyższa struktura odpowiedzi wynikać może z dominacji branż usługowej $\mathrm{i}$ handlowej $\mathrm{w}$ analizowanej próbie przedsiębiorstw.

Biorąc pod uwagę konfigurację wszystkich kategorii działań CSR realizowanych przez przedsiębiorstwa, wyniki nie są optymistyczne - żaden ze wskazanych obszarów nie przekroczył progu 50\% wskazań. Odpowiedzi w małych, średnich i dużych firmach były zbliżone, a różnice oscylowały w okolicy kilku punktów procentowych. Szczegółowy rozkład wskazań zawiera tabela 3. Mikroprzedsiębiorstwa zdecydowanie rzadziej niż pozostałe podmioty deklarują realizację zagadnień związanych z prawami człowieka, środowiskiem naturalnymi i zaangażowaniem społecznym. Taka struktura może wynikać ze zbyt ogólnego charakteru odpowiedzi. „Gdyby ochronę środowiska sprowadzić do zachowań z zakresu eko-biura, a prawa człowieka do kwestii szanowania współpracowników - odpowiedzi mikroprzedsiębiorców mogłyby się diametralnie zmienić" [Skrzek-Lubasińska i in., 2011, s. 62]. 
Tabela 3. Realizowane działania we wskazanych za istotne obszarach CSR

\begin{tabular}{|l|c|c|c|c|c|}
\hline \multirow{2}{*}{ Obszar } & \multicolumn{5}{|c|}{ Odsetek przedsiębiorstw deklarujących wykonywanie praktyk CSR } \\
\cline { 2 - 6 } w danym obszarze \\
\cline { 2 - 6 } & $\begin{array}{c}\text { Mikro } \\
\text { (N=208) }\end{array}$ & $\begin{array}{c}\text { Małe (N= } \\
\mathbf{2 5 4}\end{array}$ & $\begin{array}{c}\text { Średnie } \\
\text { (N=312) }\end{array}$ & $\begin{array}{c}\text { Duże } \\
(\mathbf{N}=96)\end{array}$ & $\begin{array}{c}\text { Próba } \\
\text { (N=870) }\end{array}$ \\
\hline $\begin{array}{l}\text { Relacje } \\
\text { z konsumentami }\end{array}$ & $40 \%$ & $48 \%$ & $43 \%$ & $46 \%$ & $43 \%$ \\
\hline $\begin{array}{l}\text { Relacje } \\
\text { z pracownikami }\end{array}$ & $39 \%$ & $54 \%$ & $47 \%$ & $55 \%$ & $45 \%$ \\
\hline Ład organizacyjny & $27 \%$ & $43 \%$ & $46 \%$ & $53 \%$ & $34 \%$ \\
\hline $\begin{array}{l}\text { Uczciwe praktyki } \\
\text { rynkowe }\end{array}$ & $28 \%$ & $37 \%$ & $38 \%$ & $39 \%$ & $32 \%$ \\
\hline Prawa człowieka & $7 \%$ & $20 \%$ & $22 \%$ & $22 \%$ & $12 \%$ \\
\hline $\begin{array}{l}\text { Środowisko } \\
\text { naturalne }\end{array}$ & $8 \%$ & $26 \%$ & $27 \%$ & $33 \%$ & $14 \%$ \\
\hline $\begin{array}{l}\text { Zaangażowanie } \\
\text { społeczne }\end{array}$ & $3 \%$ & $11 \%$ & $17 \%$ & $24 \%$ & $6 \%$ \\
\hline
\end{tabular}

Źródło: opracowanie własne na podstawie Skrzek-Lubasińska i in., 2001, s. 62.

Przedsiębiorcy biorący udział w badaniu zostali poproszeni o określenie planów związanych z wdrażaniem zasad społecznej odpowiedzialności biznesu w ich firmie w perspektywie kolejnego roku. Ponad 60\% respondentów uważa, że działania realizowane do tej pory w każdym z siedmiu obszarów CSR są wystarczające. Co piąty ankietowany nie planuje w ciągu 12 miesięcy włączać się w działania obejmujące uczciwe praktyki rynkowe, prawa człowieka i środowisko naturalne. $Z$ kolei co trzeci przedsiębiorca nie zamierza w najbliższym interwale czasowym realizować działań na rzecz społeczności lokalnych. Odsetek 5-15\% przedstawicieli badanych firm deklaruje zamiar zaangażowania się w poszczególne płaszczyzny CSR (zob. wykres 2). 


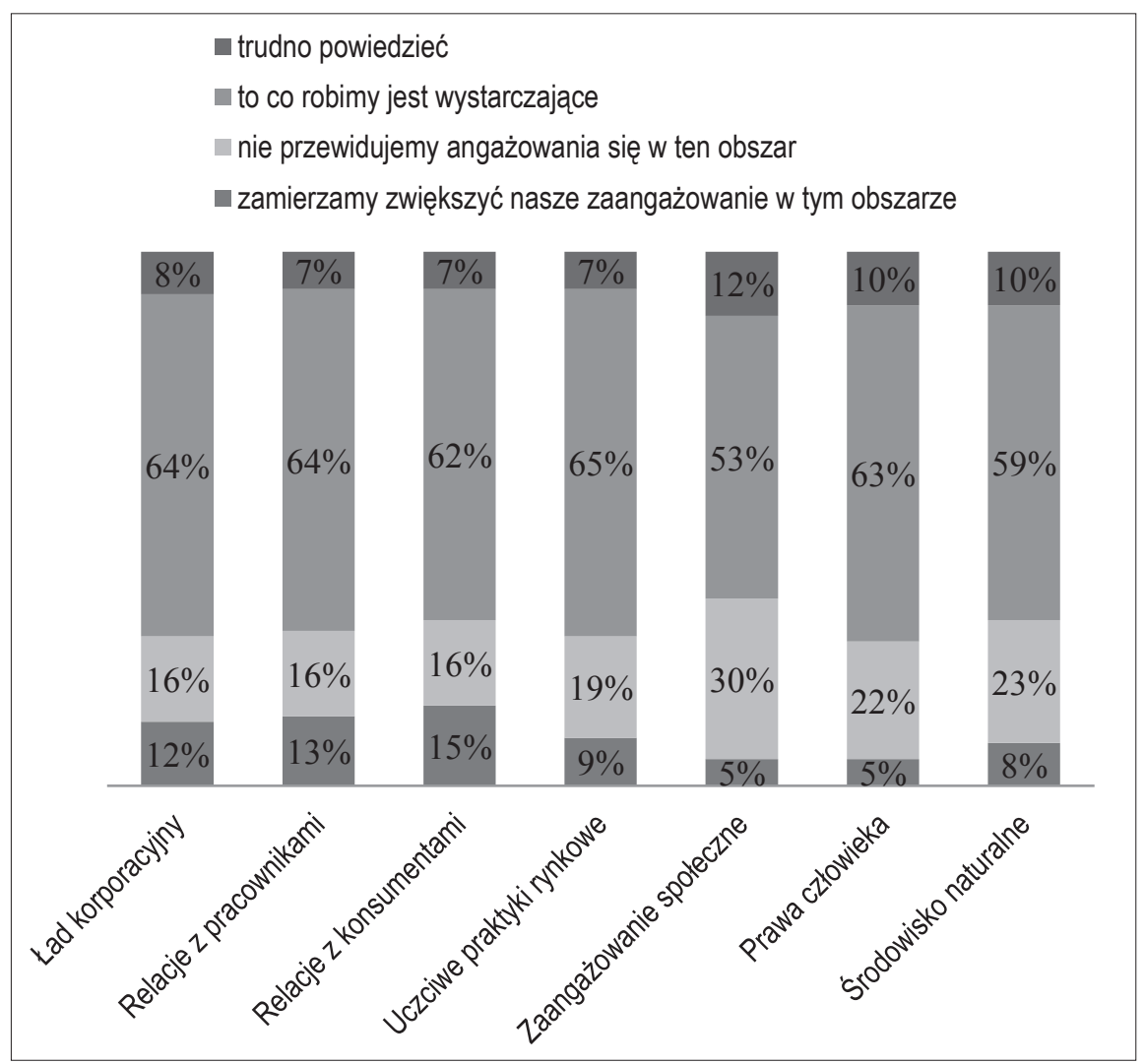

Wykres 1 . Kluczowe obszary CSR - założenia a realizacja ( $\mathrm{N}=870)$

Źródło: opracowanie własne na podstawie Lubasińska i in., 2011, s. 199.

Analiza powyższych wskazań przedsiębiorców i ich przeświadczenie o wystarczającym partycypowaniu w konkretnych obszarach CSR, przy równocześnie ograniczonej zasobności wiedzy na temat samej koncepcji (tylko 31\% ankietowanych deklaruje znajomość definicji), dowodzi, że bez zrozumienia istoty społecznej odpowiedzialności biznesu niemożliwe jest dostrzeżenie korzyści z realizacji tychże działań. 


\section{PODSUMOWANIE}

Wieloaspektowość problematyki społecznej odpowiedzialności biznesu stanowi znaczącą barierę adaptacyjną dla podmiotów z sektora małych i średnich przedsiębiorstw. Współcześnie koncepcja CSR znajduje szerokie zastosowanie m.in. w standardach międzynarodowych czy strategiach organizacyjnych większych podmiotów gospodarczych. Implikuje także powstawanie specjalnych komórek organizacyjnych, a nawet ministerstw w poszczególnych krajach zajmujących się wyłącznie tym obszarem. Jednakże zaprezentowane powyżej badania potwierdzają, że na poziomie mikrootoczenia społeczna odpowiedzialność biznesu znajduje się w początkowej fazie. Przedstawiciele sektora MSP posiadają ograniczony zasób wiedzy na temat założeń omawianej koncepcji, co powoduje niedostrzeganie benefitów (przez 58\% mikroprzedsiębiorstw oraz 65\% małych i średnich firm) płynących z wdrożenia zasad społecznie odpowiedzialnych CSR utożsamiane jest $\mathrm{w}$ owych podmiotach $\mathrm{z}$ procesem czasochłonnym i bardzo kosztownym. Istotnym problemem, zidentyfikowanym w badaniach Polskiej Agencji Rozwoju Przedsiębiorczości, jest brak posiadania przez większość firm z sektora MSP dokumentów zawierających określone wartości, misję i wizję. Zaledwie co piąte przedsiębiorstwo posiada wyżej wymienione dokumenty $\mathrm{w}$ formie pisemnej i powszechnie dostępnej. Zawierają one pojedyncze elementy koncepcji społecznej odpowiedzialności biznesu, które to $\mathrm{z}$ reguły są powiązane $\mathrm{z}$ obszarami relacji z konsumentami i kontaktów z pracownikami. Zmieniające się warunki prowadzenia działalności gospodarczej oraz wpływ coraz większej ilości czynników na pozycję rynkową firmy, zdaniem autorki, wymuszą w znacznej części również na małych i średnich przedsiębiorstwach konieczność uwzględniania potrzeb pozostałych interesariuszy. Kluczowe jest jednak wykorzystanie takiego instrumentarium CSR, które będzie powiązane z profilem działalności oraz kulturą organizacyjną przedsiębiorstwa. Kompilacja odpowiednich narzędzi i właściwej grupy odbiorców działań przyczyni się do kreowania przewagi konkurencyjnej w obecnym systemie gospodarczym. 


\section{LITERATURA}

Adamczyk J., (2009), Społeczna odpowiedzialność przedsiębiorstw, PWE, Warszawa.

Bachorski-Rudnicki M., Kroik J., (2012), CSR i zrównoważony rozwój w dobie wspótczesnej silnej konkurencji, „Problemy Jakości”, nr 1/2012, Warszawa.

Bernatt M., (2009), Społeczna odpowiedzialność biznesu. Wymiar konstytucyjny i międzynarodowy, Wydawnictwo Naukowe Wydziału Zarządzania Uniwersytetu Warszawskiego, Warszawa.

Carroll A.B., (1991), The pyramid of corporate social responsibility: Toward the moral management of organizational stakeholders, "Business Horizons", Vol. 34, Bloomington.

FOB, (2015a), Encyklopedia CSR - Społeczna odpowiedzialność biznesu, http:// odpowiedzialny biznes.pl/hasla-encyklopedii/spoleczna-odpowiedzialnosc-biznesu-csr [05.05.2015].

FOB, (2015b), Raport Odpowiedzialny biznes w Polsce 2014. Dobre praktyki, Forum Odpowiedzialnego Biznesu, Warszawa.

Friedman M., (1997), Kapitalizm i wolność, Warszawa.

ISO, (2010), Społeczna odpowiedzialność - odkrywajac ISO 26000, Warszawa.

Kazojć K., (2012), Czarny CSR - nieetyczne wykorzystanie koncepcji przez organizacje, „Studia i Prace Wydziału Nauk Ekonomicznych i Zarządzania”, WNUS, Szczecin.

Klepacka K., (2008), Corporate Social Responsibility in Poland, Det Norske Veritas, Stockholm.

Komisja Europejska, (2011), Odnowiona strategia UE na lata 2011-2014 dotyczqca społecznej odpowiedzialności przedsiębiorstw, KOM (2011) 681 wersja ostateczna, Bruksela.

Krasek M., Skwiercz B., (2007), CSR to nie filantropia, „Marketing w Praktyce”, nr 12, Warszawa.

Leon XIII, (1982), Encyklika Rerum Novarum, „Znak”, nr 332-334, Kraków.

Ministerstwo Gospodarki, (2010), CSR. Społeczna odpowiedzialność biznesu w Polsce, Warszawa.

NationMaster, (2015), http://www.nationmaster.com/\#The-Sullivan-Principles [05.05.2015].

Polańska A., (1997), Zasady podziału dochodów z pracy w świetle etyki i ekonomii [w:] W. Gasparski (red.), Etyka biznesu, PWN, Warszawa.

Skrzek-Lubasińska M., Dyjas-Pokorska A., Kudrewicz-Roszkowska M., Makuch Ł., Stanek-Kowalczyk A., Uhl H., (2011), Ocena stanu wdrażania standar- 
dów społecznej odpowiedzialności biznesu - zestaw wskaźników społecznej odpowiedzialności w mikro, matych, średnich oraz dużych przedsiębiorstwach, Polska Agencja Rozwoju Przedsiębiorczości, Warszawa.

Stafiej A.M., Prochenko P., (2004), CSR komunikowanie o społecznej odpowiedzialności biznesu, „Brief”, nr 4, Warszawa.

Williamson N., Stampe-Knippel A., Weber T., (2014), Corporate Social Responsibility. National Public Policies in the European Union, ICF International, London.

World Business Council for Sustainable Development, (2002), The Business Case for Sustainable Development, Switzerland.

Zinczuk B., (2011), Społeczna odpowiedzialność biznesu i jej znaczenie we wspótczesnym przedsiębiorstwie, „Zarządzanie i Edukacja”, Dwumiesięcznik Szkoły Wyższej im. B. Jańskiego, nr 76-77, maj-czerwiec/lipiec-sierpień, Warszawa.

\title{
CORPORATE SOCIAL RESPONSIBILITY IN THE SME'S SECTOR
}

\begin{abstract}
A b s t r a c t: The idea of Corporate Social Responsibility find its roots in the philosophical concept of responsibility, whereby the consequence of giving human freedom is to require him to be responsible. Leading of economic activity in times of instable environment requires, from the company owners, development and keeping such action strategy which will, besides financial scores achievements, also be the cause for the close environment to grow. Implementation of social assumptions of responsibility in business in smaller units is indirectly limited because of wrong interpretation of the concept aim, or even lack of knowledge by entrepreneurs. This article have theoretical- review character. In publication there are information about good and bad practices of CSR used by polish and European companies. The analysis has also been subjected to the spectrum of operators of the responsible business conduct tools
\end{abstract}

K e y w o r d s: CSR; corporate social responsibility; SME's sector. 